\title{
Water Potential and Viability of Seeds of Eugenia (Myrtaceae), a Tropical Tree Species, Based upon Different Levels of Drying
}

\author{
Liliana Ferreira Delgado ${ }^{1}$ and Claudio José Barbedo ${ }^{2 *}$ \\ ${ }^{1}$ Instituto de Botânica; Programa de Pós-Graduação em Biodiversidade Vegetal e Meio Ambiente; Av Miguel \\ Stefano, 3687; 04301-012; São Paulo - SP - Brasil. ${ }^{2}$ Instituto de Botânica; Núcleo de Pesquisa em Sementes; Av. \\ Miguel Stefano, 3687; 04301-012; São Paulo - SP - Brasil
}

\begin{abstract}
The aim of the present work was to study the water potential and viability of Eugenia based upon different levels of drying. The seeds showed high water content at shedding and were sensitive to desiccation; however, the level of this sensitivity (water content) varied among the species. Five target drying levels were defined according to the critical levels of hydration. Results showed that water potential seemed to be more reliable than water content. It was hypothesize that the differences in desiccation tolerance, as well as recalcitrance, among the seeds of different species could be related to the maturity level of these seeds during shedding from the mother plant. Consequently, this could be a result of the evolution on how far the maturation process could represent an advantage for the species propagation. This could also mean that Eugenia seeds were dispersed at a maturity stage similar to that observed in immature orthodox seeds.
\end{abstract}

Key words: desiccation tolerance; drying; seed water relations; recalcitrance

\section{INTRODUCTION}

The ability to dry without dying found in a few animals, plants and microbes allows them to survive during extended periods and, specifically expressed in the seeds, allows them to be stored and distributed widely (Alpert 2005). By removing the water from the seeds and decreasing the environmental temperature seed aging rates can be slowed down; these procedures are also important to control the fungal proliferation. However, drying is only possible for desiccation tolerant seeds, which are known as orthodox seeds (Roberts 1973). The seeds with relatively high lethal limits to desiccation (i.e. recalcitrant seeds) must be maintained at high water content, and consequently at temperatures above $0^{\circ} \mathrm{C}$. Such conditions often allow the seeds to maintain a high metabolism rate, therefore making their conservation difficult. Even though there are definitions of desiccation tolerance (Alpert and Oliver 2002; Berjak 2006), desiccation sensitivity is not an all-or-nothing situation. Instead, there are different levels among the species or even in the same species, depending on the environmental conditions in which the seeds are developed (Berjak and Pammenter 1994; Walters 2000; Daws et al. 2004).

Desiccation tolerance is often described based on the water content values, meaning the amount or proportion of seed water content. More recently, researchers have described this desiccation

*Author for correspondence: claudio.barbedo@pesquisador.cnpq.br 
tolerance in terms of water potential (Sun and Liang 2001; Sun 2002; Villela et al. 2003; Daws et al. 2006), or water activity (Sun 2002; Faria et al. 2004), which could better describe the status of the water and, probably, the real desiccation tolerance of the seeds.

According to Walters et al. (2005), fully hydrated seeds $(\Psi \geq \sim-1 \mathrm{MPa})$ could grow. Stress responses which could be detected at hydration levels lower than -1MPa were initially the expression of stressrelated proteins and nucleic acid repair pathways $(-1$ to $\sim-3 \mathrm{MPa})$ followed by the rampant production of free radicals and loss of membrane integrity $(-5$ to $\sim-12 \mathrm{MPa})$. At water potentials below about $-15 \mathrm{MPa}$, cells would be in the dry state. As embryos of orthodox seeds mature, they acquire tolerance to progressively lessened water potentials in discrete steps, coinciding with discrete patterns of gene expression. Therefore, five critical moisture levels have been identified at $-1.8,-5,-12,-50$ and $-180 \mathrm{MPa}$, suggesting that desiccation tolerance could be not quantitative per se, but rather represents a series of mechanisms designed to meet the discrete challenges (Walters 2000).

Tropical rain forests are considered to have comparatively more species with desiccationsensitive seeds than other regions due to the high water availability throughout most of the year (Barbedo and Bilia 1998). In this case, the high water content of desiccation sensitive seeds, which allows rapid germination, may also reduce the duration of seed exposure to predation and for large-seeded species could increase the resourceuse efficiency (Pritchard et al. 2004; Daws et al. 2005). However, conservation of these species in seed banks is quite difficult and the alternative methods used to guarantee biodiversity are often expensive (Barbedo and Marcos Filho 1998).

Eugenia (Myrtaceae) is an important genus in Brazil comprising species occurring in almost all parts of the country and ecosystems, including the Brazilian Atlantic forest (Salgueiro et al. 2004), which is one of the world's 25 biodiversity hotspots for conservation priorities (Myers et al. 2000). Several species of this genus are ornamental and besides their ecological use, they could be included as urban trees and for economic or pharmacological aims (Delgado and Barbedo 2007). For example, xanthine oxidase inhibitory activity and antifungal agents used in the treatment of dermatophyte infections were found in $E$. uniflora (Schmeda-Hirschmann et al. 1987; Souza et al. 2002).

Despite their importance, data on the seed behavior of these species are scarce and not conclusive. Silva et al. (1993), for example, suggested that the diaspores of Eugenia involucrata should be submitted to shade drying techniques after the fruit has been pulped, but Barbedo et al. (1998) observed that only nondehydrated diaspores maintained their viability after a 120-day storage. As a matter of fact, lowering water content has proved to be deleterious for a range of recalcitrant seeds, declining their storage lifespan at this 'subimbibed' condition (Berjak and Pammenter 2008 and references therein).

Seeds of many Brazilian tropical tree species in the genus Eugenia (Myrtaceae) show high water content at shedding and have been considered to be sensitive to desiccation. However, among Eugenia seeds, there are different desiccation sensitivity levels based on the water content, as reported by different authors (Barbedo et al. 1998; Anjos and Ferraz 1999; Andrade and Ferreira 2000; Andrade et al. 2003; Delgado and Barbedo 2007; Masetto et al. 2008).

Delgado and Barbedo (2007), for example, identified three different levels of critical water content (described as fresh mass basis) for the seeds of six species of Eugenia, from 65 (the most sensitive seeds) to $45 \%$ (the least sensitive seeds). However, there is little information on the desiccation tolerance for the seeds of Eugenia in terms of water potential, making it difficult to understand the metabolic events occurring at different levels of water activity, as described by Vertucci and Farrant (1995) and Walters et al. (2005). In the present work, we describe the relationship between the water potential and viability for the seeds of six Brazilian species of Eugenia (E. brasiliensis Lam., E. cerasiflora Miq., E. involucrata DC., E. pyriformis Camb., E. umbelliflora Berg. and E. uniflora L.) after different levels of drying.

\section{MATERIAL AND METHODS}

\section{Plant material}

Ripe fruits were collected directly from at least four trees of each species at the beginning of natural fruit dispersion. The fruits of Eugenia brasiliensis Lam. and E. involucrata DC. were obtained from Mogi-Guaçu (22 ${ }^{\circ} 15-16^{\prime}$ S, 47 ${ }^{\circ} 8-12^{\prime}$ 
W; Cwa, according to Köppen climate classification), those of E. uniflora L., $E$. pyriformis Camb. and E. cerasiflora Miq. in São Paulo (2327-38' S, 46 ${ }^{\circ} 36-37^{\prime} \mathrm{W}$; Cwb) and of $E$. umbelliflora Berg in Cananéia $\left(25^{\circ} 05^{\prime} \mathrm{S}, 47^{\circ} 55^{\prime}\right.$ W; Af). The seeds were then removed from the fruits manually, bulked and those visually damaged by insects or fungi were discarded. Seeds were then sampled for analysis of water content, water potential and germination ability. The remaining seeds were stored in the polyethylene bags at $8^{\circ} \mathrm{C}$ (as these seeds were not chilling sensitive, according to Barbedo et al. 1998 and Maluf et al. 2003) for not longer than five days.

\section{Analysis of water content, water potential and germinability}

The seeds were analyzed for the water content (WC), water potential $(\Psi)$ and germination. WC (g $\mathrm{H}_{2} \mathrm{O} / \mathrm{g}$ dry mass, $\mathrm{g} \mathrm{g}^{-1}$ ) was determined by drying at $103^{\circ} \mathrm{C}$ for $17 \mathrm{~h}$ (Ista 1985) using five seeds for each replicate. Embryo $\left(\Psi_{\mathrm{e}}\right)$ and seed coat $\left(\Psi_{\mathrm{c}}\right)$ water potential $(\mathrm{MPa})$ were measured using a WP4 dew point potentiameter (Decagon Devices, Pullman, USA) operating in a temperaturecontrolled room $\left(24 \pm 2^{\circ} \mathrm{C}\right)$, with five seed coats or embryos in each replication. Germination tests were carried out in germinators MA400 (Marconi, Piracicaba, Brazil) at $25 \pm 1^{\circ} \mathrm{C}$ and constant fluorescent light, with $100 \% \mathrm{RH}$ given by a flux of water in the back wall. Seeds were placed in the germination paper rolls (10 seeds per roll) and then evaluated every 15 days scoring germinated seeds (minimum $5 \mathrm{~mm}$ radicle emergence) and the normal seedling development (based on descriptions of a normal seedling reported by Delgado and Barbedo 2007).

\section{Germination ability at different water contents and water potentials}

Five target drying levels were defined based on the WC $\left(1.0,0.7,0.4,0.3\right.$ and $\left.<0.3 \mathrm{~g} \mathrm{~g}^{-1}\right)$, which should correspond approximately to five levels of hydration described by Vertucci and Farrant (1995). Seeds were submitted to both intermittent and continuous drying methods. Intermittent drying consisted of placing the seeds in an oven with a constant flux of air at $40 \pm 1^{\circ} \mathrm{C}$ for $8 \mathrm{~h}$, following a $16 \mathrm{~h}$ rest period $\left(25 \pm 5^{\circ} \mathrm{C}\right)$. This procedure was repeated until the last drying level was achieved. Continuous drying consisted of maintaining the seeds in a sealed chamber containing silica gel $\left(25 \pm 2^{\circ} \mathrm{C}\right)$. Both, the water potential and germination ability were analyzed based upon the samples of each species seeds, each drying method and each drying level.

\section{Statistical analysis}

All the experiments were carried out as a completely randomized design with four replicates, in a $2 \times 5$ factorial design (drying method $\mathrm{x}$ desiccation level). Results were submitted to F-test at the 5\% level (Santana and Ranal 2004). Seedling development as well as the relationship between the water potential and germination rates were also analyzed by using the Probit analysis and the $\Psi$, in which $10 \%$ of normal seedling development was lost LPS $_{10}$, considered to be the beginning of vigor loss), the $\Psi$ in which $50 \%$ viability was lost $\left(\mathrm{LP}_{50}\right)$ and $\Psi$ in which $90 \%$ viability was lost $\left(\mathrm{LP}_{90}\right.$, considered to be the lethal $\Psi$ for the seed lot) were estimated.

\section{RESULTS AND DISCUSSION}

The results showed no differences in $\Psi$, germination or seedling development between the continuous or intermittent drying method. Therefore, the values were reported as the average of both the methods for each drying level. However, the drying time was different for each drying method, faster in the oven-intermittent ( $c a$. $\left.0.0026 \mathrm{~g} \mathrm{~g}^{-1} \mathrm{~h}^{-1}\right)$ compared to silica gel-continuous (ca. $0.0008 \mathrm{~g} \mathrm{~g}^{-1} \mathrm{~h}^{-1}$ ). Recalcitrant seeds can survive at lower $\mathrm{WC}$ if they are dried rapidly (Pammenter et al. 2002). The present study showed that such differences probably did not occur because the drying, for both the methods, took place within the days instead of hours as described by Pammenter et al. (2002).

Almost all WC target values were achieved, but some levels were not obtained for all the species (Table 1). Interestingly, within the same WC, embryos of different species showed high variation on $\Psi$. For example, at $0.7 \mathrm{~g} \mathrm{~g}^{-1}, \Psi_{\mathrm{e}}$ varied from $-2.5 \mathrm{MPa}$ (hydration level IV described by Vertucci and Farrant 1995, in which the water state would be a concentrated solution), for Eugenia umbelliflora, to $-12.6 \mathrm{MPa}$ (hydration level II or III, in which the water state would be either glass/hydrophobic or hydrophilic), for Eugenia pyriformis. This could explain the differences between the desiccation tolerance behaviors as for the WC of Eugenia species described by Delgado and Barbedo (2007), i.e., 
higher in E. umbelliflora than in E. pyriformis. According to Sun (2002), the response of plant tissues to desiccation is related to the thermodynamic and kinetic status of tissue water, rather than to actual WC. At the same WC, embryos of $E$. pyriformis retained water more strongly than $E$. umbelliflora, i.e., in a physiologically drier pattern.

Interestingly, there was no relation between $\Psi_{\mathrm{e}}$ and
$\Psi_{c}$ (Fig. 1). Considering that most of the values were higher for $\Psi_{\mathrm{e}}$ than for $\Psi_{\mathrm{c}}$ and there was also a putatively hygroscopic equilibrium between these tissues, one could consider some active process for maintaining a minimum hydration level of the embryo. Furthermore, this difference in $\Psi$ could be seen as a strategy to reduce the risk of embryo death by desiccation.

Table 1 - Water content achieved (WCa, in $\mathrm{g} \cdot \mathrm{g}^{-1}$ ) and water potential ( $\psi$, in MPa) according to water content expected (WCe, in g. $\mathrm{g}^{-1}$ ). Seed treatments were carried out for six species of Eugenia after different drying periods, as well as an additional treatment consisted of drying seeds to values below $0.3 \mathrm{~g}^{-\mathrm{g}^{-1}}(<-30 \mathrm{MPa})$.

\begin{tabular}{lcccccccc}
\hline Species of & \multicolumn{2}{c}{ WCe: 1.0 } & \multicolumn{2}{c}{ WCe: 0.7 } & \multicolumn{2}{c}{ WCe: $\mathbf{0 . 4}$} & \multicolumn{2}{c}{ WCe: 0.3} \\
\hline Eugenia & WCa & $\psi$ & WCa & $\psi$ & WCa & $\psi$ & WCa & $\psi$ \\
E. uniflora & 1.1 & -3.6 & 0.7 & -6.3 & 0.4 & -43.2 & 0.3 & -45.6 \\
E. brasiliensis & 1.0 & -4.5 & 0.7 & -7.9 & 0.4 & -14.1 & 0.3 & -20.7 \\
E. involucrata & 1.0 & -6.7 & 0.7 & -9.5 & - & - & 0.3 & -42.5 \\
E. pyriformis & 0.9 & -10.6 & 0.7 & -12.6 & - & - & 0.3 & -21.9 \\
E. umbelliflora & - & - & 0.7 & -2.5 & 0.4 & -11.3 & - & - \\
E. cerasiflora & 1.1 & -2.6 & - & - & - & - & 0.3 & -29.9 \\
\hline
\end{tabular}

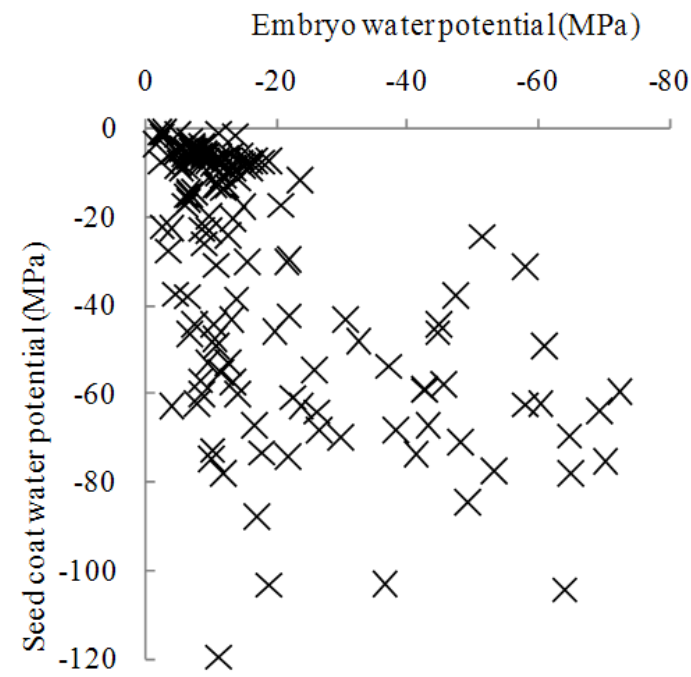

Figure 1 - Relationship between embryo water potential and seed coat water potential for seeds of six species of Eugenia (E.uniflora, E. brasiliensis, E. involucrata, E. pyriformis, E. umbelliflora, E. cerasiflora) at different drying levels.

As described by Pammenter and Berjak (2000), some temperate species could avoid this risk by shedding their recalcitrant seeds during the fall and winter and, in this case, low temperatures and low vapor pressure deficit would slow the water loss. For Eugenia species aimed at the present work, they probably developed their own mechanisms to prevent the water loss by spreading their seeds either in spring or summer, i.e., throughout the hottest seasons.
The hydration level at which Eugenia seeds began to lose vigor $\left(\mathrm{LPS}_{10}\right)$ depended on the species (Fig. $2)$. Therefore, for $E$. cerasiflora and $E$. umbelliflora, it started as early as $\Psi_{\mathrm{e}}$ reached, respectively, -0.02 and $-1.23 \mathrm{MPa}$ (hydration level V, Walters et al. 2002), whereas in the other species, this occurred at -2 to $-4 \mathrm{MPa}$ (hydration level IV).

This could mean a significant change, for example, on the state of the water (solution for the level V, 
syrup for IV) and on mechanical strains (at level V cells are under positive turgor pressure, at level IV they can shrink, Walters et al. 2002 and references therein). As germination ability was not affected even for E. cerasiflora and E. umbelliflora, one could consider that, at this level of drying, seeds underwent desiccation-related damages in different tissues. On the other hand, seeds of all
Eugenia species showed $\mathrm{LP}_{50}$ within the same level of hydration (level III, -5 to approximately -12MPa). A wider range of $\Psi_{\mathrm{e}}$ among species was observed for the limits of desiccation tolerance $\left(\mathrm{LP}_{10}\right)$ which varied from $-19.6 \mathrm{MPa}(E$. brasiliensis, level of hydration III) to $-82.14 \mathrm{MPa}$ (E. cerasiflora, level II).
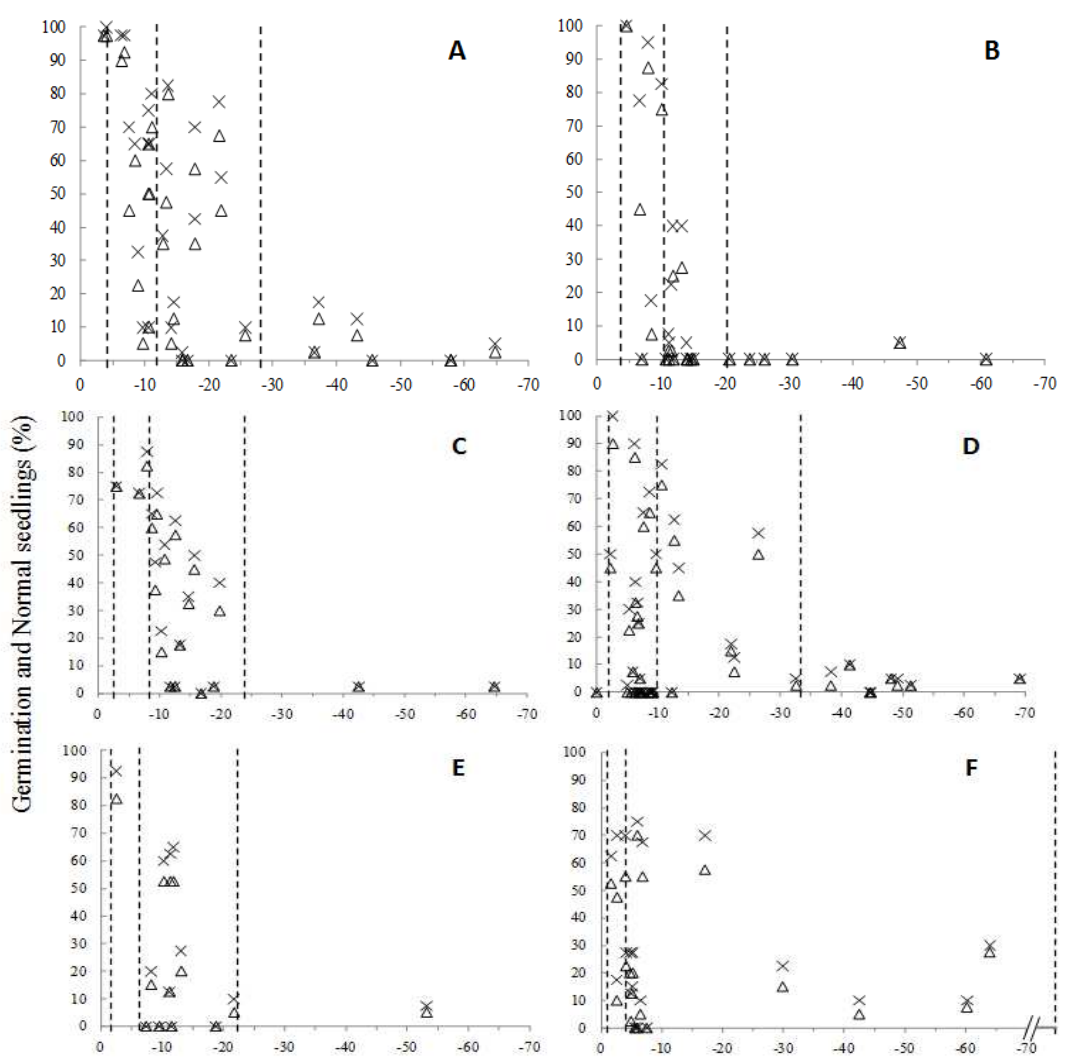

Figure 2 - Germination (x) and normal seedling development $(\Delta)$ according to water potential for seeds of six species of Eugenia after different periods of drying. A. E. uniflora; B. E. brasiliensis; C. E. involucrata; D. E. pyriformis; E. E. umbelliflora; F. E. cerasiflora. Dotted lines represent, from the left to the right, $\mathrm{LPS}_{10}, \mathrm{LP}_{50}$ and $\mathrm{LP}_{90}$.

When seeds were grouped under five targeted WCs, the hydration level in which seeds began to lose viability varied widely among species (Fig. 3). Thus, for E. uniflora it started as early as WC changed from 1.0 to $0.7 \mathrm{~g} \mathrm{~g}^{-1}$, which would correspond to reaching the hydration level IV, whereas for E. brasiliensis, E. involucrata and $E$. pyriformis this occurred only when WC was reduced to $0.4 \mathrm{~g} \mathrm{~g}^{-1}$ (hydration level III). Conversely, the beginning of seed viability loss occurred when $\Psi_{\mathrm{e}}$ changed from -5/-10MPa (hydration level IV) to $-10 /-20 \mathrm{MPa}$ (level III), as shown in Fig. 4. According to Walters et al.
(2002), embryos that were recalcitrant could not be dried below -10 to $-15 \mathrm{MPa}$. However, Fig. 4 showed that the viability was not lost at $-20 \mathrm{MPa}$ for most of the species, i.e. when cells were in the dry state (Walters et al. 2005).

Studies on seed desiccation tolerance based upon $\Psi$ have been developed (Pritchard 1991; Farrant and Walters 1998; Eira et al. 1999; Sun and Liang 2001; Daws et al. 2006), but much less than those based upon the WC. However, $\Psi$ should better indicate the status of the water than the WC (Vertucci and Farrant 1995; Villela and Marcos Filho 1998; Sun 2002). 

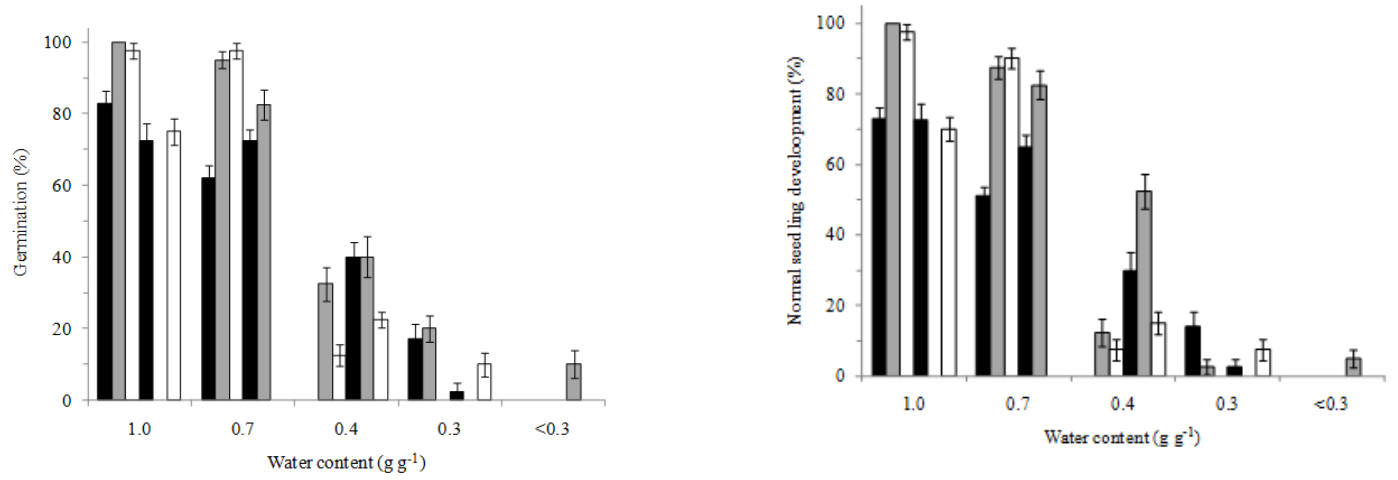

Figure 3 - Germination and normal seedling development of six species of Eugenia (from the left to the right: E. uniflora, E. brasiliensis, E. involucrata, E. pyriformis, E. umbelliflora and $E$. cerasiflora) according to water content of the embryo.
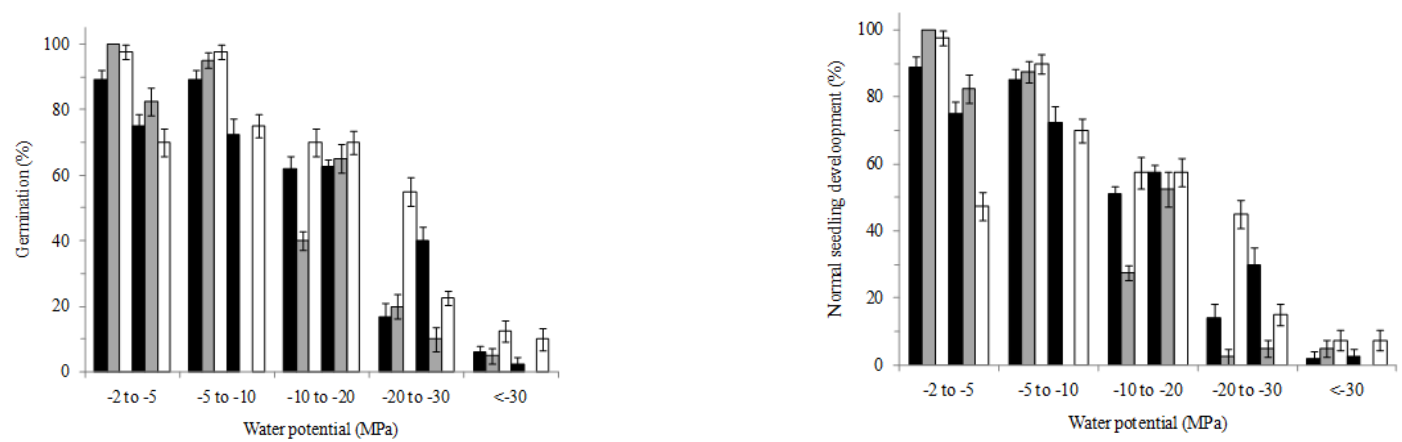

Figure 4 - Germination and normal seedling development of six species of Eugenia (from the left to the right: E. uniflora, E. brasiliensis, E. involucrata, E. pyriformis, E. umbelliflora and $E$. cerasiflora) according to water potential of the embryo.

The results obtained in the present work corroborated that idea, demonstrating that $\Psi$ of the seeds of Eugenia described the beginning of the viability loss, standardizing the behavior of different species. Also, the lethal $\Psi$ suggested the vulnerability of these seeds to a natural drying after the dispersion. Results obtained herewith also corroborated that $\Psi$ seemed to be more reliable than WC. It was also important to notice that the seeds of Eugenia species appeared to be more tolerant to desiccation than most of recalcitrant seeds described in the literature which did not tolerate the water loss as negative as $-15 \mathrm{MPa}$. The relation between the water potential and hydration levels depends on the maturity of the seeds (Vertucci and Farrant 1995; Walters et al. 2005). Therefore, the differences in desiccation tolerance among the seeds of different species might be related to the maturity level of these seeds in which shedding occurs.
An interesting relation between the seed maturity and desiccation tolerance was described by Daws et al. $(2004,2006)$, based on the heat sum from the beginning of seed formation up to its dispersion, concluding that identifying the maximum level of desiccation tolerance for a particular species could be troublesome. They found different desiccation tolerance levels for the seeds of the same species, but from different latitudes. Therefore, the different desiccation tolerance levels shown by the seeds could be merely the differences in maturity at shedding. According to Black et al. (2002), gene expression in developing seeds can be modified by water status, therefore, this effect could participate in the establishment of desiccation tolerance. On the other hand, it is assumed that recalcitrance should be a continuum, not an all-or-nothing situation (Berjak and Pammenter 1994). Therefore, desiccation tolerance levels and consequently recalcitrance might be given by differences in 
evolutionary advantage for the species propagation in terms of maturation process.

According to Barbedo and Bilia (1998), recalcitrant seeds were probably selected in a habitat that permitted seedling development throughout the year. Seed drying in such environment would be another limiting factor for the germination: additional water dependence. Seeds which did not germinate immediately probably did not succeed either due to the competition with other species or as air-dry seeds stored in bare soil, causing deterioration or germination under poor and shady conditions. Such unfavourable conditions could play as inhibitors to germination during seed maturation. During maturation, ABA levels increase, the highest concentrations in mid-development (Black et al. 2002), but recalcitrant seeds could be dispersed prior to ABA levels could reach a minimum level to prevent the germination. Thus, some seeds could even germinate before shedding (vivipary), as described for Inga sp. (Bilia and Barbedo 1997; Farnsworth 2000; Bonjovani and Barbedo 2008). The water potential values obtained for Eugenia dispersed seeds coincided with immature orthodox seeds.

\section{ACKNOWLEDGEMENTS}

The authors wish to thank Jose Marcio R. Faria and Miriam T. S. Eira for reviewing the original manuscript and Odair Vieira for assistance with language review. Financial support for this work and a fellowship for CJ Barbedo from the Conselho Nacional de Desenvolvimento Científico e Tecnológico - CNPq (Proc. 477640/2009-5 and 308045/2007-6308045/2007-6) and the Fundação de Amparo a Pesquisa no Estado de São Paulo FAPESP (Proc. 2002/12215-7 and 2005/04139-7) are gratefully acknowledged. We also wish to thank the Secretaria da Educação do Estado de São Paulo for a scholarship for the first author and the Programa de Pós-Graduação em Biodiversidade Vegetal e Meio Ambiente for the post-graduation course.

\section{REFERENCES}

Alpert P. The limits and frontiers of desiccation-tolerant life. Integr Comp Biol. 2005; 45: 685-695.
Alpert P, Oliver MJ. Drying without dying. In: Black $\mathrm{M}$, Pritchard HW, editors. Desiccation and survival in plants: drying without dying. Wallingford/ New York: CAB International; 2002. p.3-43.

Andrade ACS, Cunha R, Souza AF, Reis RB, Almeida KL. Physiological and morphological aspects of seed viability of a neotropical savannah tree, Eugenia dysenterica DC. Seed Sci Tecnol. 2003; 31: 125-137.

Andrade RNB, Ferreira AG. Germinação e armazenamento de sementes de uvaia (Eugenia pyriformis Camb.) - Myrtaceae. Rev Bras Sementes. 2000; 22: 118-125.

Anjos AMG, Ferraz IDK. Morfologia, germinação e teor de água das sementes de araçá-boi (Eugenia stipitata ssp. sororia). Acta Amaz. 1999; 29: 337-348.

Barbedo CJ, Bilia DAC. Evolution of research on recalcitrant seeds. Sci Agric. 1998; 55(special): 121125.

Barbedo CJ, Marcos-Filho J. Tolerância à dessecação de sementes. Acta Bot Bras. 1998; 12: 145-164.

Barbedo CJ, Kohama S, Maluf AM, Bilia DAC. Germinação e armazenamento de diásporos de cerejeira (Eugenia involucrata DC. - Myrtaceae) em função do teor de água. Rev Bras Sementes. 1998; 20: 184-188.

Berjak P. Unifying perspectives of some mechanisms basic to desiccation tolerance across life forms. Seed Sci Res. 2006; 16: 1-15.

Berjak P, Pammenter NW. Recalcitrance is not an allor-nothing situation. Seed Sci Res. 1994; 4: 263-264.

Berjak P, Pammenter NW. From Avicennia to Zizania: seed recalcitrance in perspective. Ann Bot. 2008;101: 213-228.

Bilia DAC, Barbedo CJ. Estudos de germinação e armazenamento de sementes de Ingauruguensis Hook. et Arn. Científica. 1997; 25: 379-391.

Black M, Obendorf RL, Pritchard HW. Damage and tolerance in reptrospect and prospect. In: Black M, Pritchard HW, editors. Desiccation and survival in plants: drying without dying. Wallingford/ New York: CAB International; 2002. p.367-372.

Bonjovani MR, Barbedo CJ. Sementes recalcitrantes: intolerantes a baixas temperaturas? Embriões recalcitrantes de Inga vera Willd. subsp. affinis (DC.) T.D.Penn. toleram temperatura sub-zero. Rev Bras Bot. 2008; 31: 345-356.

Daws MI, Cleland H, Chmielarz P, Gorian F, Leprince O, Mullins CE, Thanos CA, Vandvik V, Pritchard H. Variable desiccation tolerance in Acer pseudoplatanus seeds in relation to developmental conditions: a case of phenotypic recalcitrance? Func Plant Biol. 2006; 33: 59-66.

Daws MI, Garwood NC, Pritchard HW. Traits of recalcitrant seeds in a semi-deciduous tropical forest in Panamá: some ecological implications. Func Ecol. 2005; 19: 874-885. 
Daws MI, Lydall E, Chmielarz P., Leprince O, Matthews S, Thanos CA, Pritchard H. Developmental heat sum influences recalcitrant seed traists in Aesaculus hippocastaneum across Europe. New Phytol. 2004; 162: 157-166.

Delgado LF, Barbedo CJ. Tolerância à dessecação de sementes de espécies de Eugenia. Pesq Agrop Bras. 2007; 42: 265-272.

Eira MT, Walters C, Caldas LS. Water sorption properties in Coffea spp. seeds and embryos. Seed Sci Res. 1999; 9: 321-330.

Faria JMR, Van Lammeren AAM, Hilhorst HWM. Desiccation sensitivity and cell cycle aspects in seeds of Inga vera subsp. affinis. Seed Sci Res. 2004; 14: 165-178.

Farnsworth E. The ecology and physiology of viviparous and recalcitrant seeds. Ann Rev Ecol Syst. 2000; 31: 107-138.

Farrant JM, Walters C. Ultrastructural and biophysical changes in developing embryos of Aesculus hippocastaneum in relation to acquisiton of tolerance to drying. Physiol Plantarum. 1998; 104: 513-524.

Maluf AM, Bilia DAC, Barbedo CJ. Drying and storage of Eugenia involucrata DC. seeds. Sci Agric. 2003; 60: 471-475.

Myers N, Mittermeier RA, Mittermeier CG, Fonseca GAB, Kent J. Biodiversity hotspots for conservation priorities. Nature. 2000; 403: 853-858.

Masetto TE, Faria JMR, Davide AC, Silva EAA. Desiccation tolerance and DNA integrity in Eugenia pleurantha O. Berg. (Myrtaceae) seeds. Rev Bras Sementes. 2008; 30: 175-180.

Pammenter NW, Berjak P. Evolutionary and ecological aspects of recalcitrant seed biology. Seed Sci Res. 2000; 10: 301-306.

Pammenter NW, Berjak P, Wesley-Smith J, Willigen $\mathrm{CV}$. Experimental aspects of drying and recovery. In: Black M, Pritchard HW, editors. Desiccation and survival in plants: drying without dying. Wallingford/ New York: CAB International; 2002. p. 93-110.

Pritchard HW. Water potential and embryonic axes viability in recalcitrant seeds of Quercus rubra. Ann Bot. 1991; 67: 43-49.

Pritchard HW, Daws MI, Fletcher BJ, Gaméné CS, Msanga HP, Omondi W. Ecological correlates of seed desiccation tolerance in tropical african dryland trees. Am J Bot. 2004; 91: 863-870.

Roberts EH. Predicting the storage life of seed. Seed Sci Technol. 1973; 1: 499-514.

Salgueiro F, Felix D, Caldas JF, Margis-Pinheiro M, Margis R. Even population differentiation for maternal and biparental gene markers in Eugenia uniflora, a widely distributed species from the Brazilian coastal Atlantic rain forest. Divers Dist. 2004; 10: 201-210.
Santana DG, Ranal MA. Análise da germinação: um enfoque estatístico. Brasília: Ed Universidade de Brasília; 2004.

Schmeda-Hirschmann G, Theoduloz C, Franco L, Ferro EB, Arias AR. Preliminary pharmacological studies on Eugenia uniflora leaves: xanthine oxidase inhibitory activity. J Ethnopharm. 1987; 21: 183-186.

Silva A, Figliolia MB, Aguiar IB. Secagem, extração e beneficiamento de sementes. In: Aguiar IB, PinãRodrigues FCM, Figliolia MB, editors. Sementes florestais tropicais. Brasília: Abrates; 1993. p.303331.

Silva CV, Bilia DAC, Barbedo CJ. Fracionamento e germinação de sementes de uvaia (Eugenia pyriformis Cambess. - Myrtaceae). Rev Bras Bot. 2003; 26: 213-221.

Silva CV, Bilia DAC, Barbedo CJ. Fracionamento e germinação de sementes de Eugenia. Rev Bras Sementes. 2005; 27: 86-92.

Souza LKH, Oliveira CMA, Ferri PH, Santos SC, Oliveira Junior JG, Miranda ATB, Lião LM, Silva MRR. Antifungal properties of Brazilian Cerrado plants. Braz J Microbiol. 2002; 33: 247-249.

Sun WQ, Liang YH. Discrete levels of desiccation sensitivity in various seeds as determined by the equilibrium dehydration method. Seed Sci Res. 2001; 11: 317-323.

Sun WQ. Methods for the study of water relations under desiccation stress. In: Black M, Pritchard HW, editors. Desiccation and survival in plants: drying without dying. Wallingford/ New York: CAB International; 2002. p. 47-91.

Vertucci CW, Farrant JM. Aquisition and loss of desiccation tolerance. In: Kigel J, Galili G, editors. Seed development and germination. New York: Marcel Dekker, Inc.; 1995. p.237-271

Villela FA, Marcos Filho J. Estados energéticos e tipos de água na semente. Rev Bras Sementes. 1998; 20: 317-321.

Villela FA, Marcos Filho J, Novembre ADLC. Estado energético da água na semente de milho no processo de germinação. Rev Bras Sementes. 2003; 25: 95-100.

Walters C, Farrant JM, Pammenter NW, Berjak P. Desiccation stress and damage. In: Black M, Pritchard HW, editors. Desiccation and survival in plants: drying without dying. Wallingford/ New York: CAB International; 2002. p.263-291.

Walters C. Levels of recalcitrance in seeds. Rev Bras Fisiol Veg. 2000; 12(special): 7-21.

Walters C, Hill LM, Wheeler J. Dying while dry: kinetics and mechanisms of deterioration in desiccated organisms. Integr Comp Biol. 2005; 45: 751-758.

Received: November 17, 2010; Revised: July 02, 2011; Accepted: May 15, 2012. 